\title{
PENGARUH PUPUK KANDANG KAMBING DAN SAPI TERHADAP PERTUMBUHAN Azolla microphylla
}

\author{
Effect of Cattle and Goat Manures on Growth of Azolla microphylla \\ Faiz Al Arif ${ }^{1}$, Herry Susanto ${ }^{1 *}$, Hidayat Pujisiswanto ${ }^{2}$ \\ ${ }^{1}$ Jurusan Agroteknologi, Fakultas Pertanian, Universitas Lampung \\ ${ }^{2}$ Jurusan Agronomi dan Hortikultura, Fakultas Pertanian, Universitas Lampung \\ Jl. Sumantri Brojonegoro No 1 Gedung Meneng, Bandar Lampung 35145 \\ *E-mail Korespondensi: herry.susanto@fp.unila.ac.id
}

\begin{abstract}
ABSTRAK
Azolla microphylla merupakan jenis tumbuhan paku-pakuan yang berukuran kecil, hidup di perairan dan bermanfaat salah satunya sebagai pupuk organik pada pertanaman padi sawah. Dilihat potensinya dan penggunaannya semakin banyak perlu dilakukannya suatu penelitian yang dapat meningkatkan pertumbuhan dan populasi A. microphylla. Penelitian dilakukan di Rumah Kaca dan Laboratorium Ilmu Gulma Fakultas Pertanian, Universitas Lampung pada bulan Maret sampai April 2020. Penelitian menggunakan Rancangan Acak Lengkap dengan empat ulangan dan enam perlakuan sehingga terdapat 24 satuan percobaan. Media yang digunakan berupa tanah dan air 10,5 liter diisikan pada nampan yang berukuran $30 \mathrm{~cm} \times 35 \mathrm{~cm}$. Perlakuan yang digunakan $\mathrm{KO}=$ tanpa pupuk kandang, $\mathrm{K} 1$ = pupuk kandang kambing 42 gram/ air 10,5 liter, K2 = pupuk kandang kambing 31,5 gram/air 10,5 liter dan sapi 10,5 gram/ air 10,5 liter, K3 = pupuk kandang kambing 21 gram/air 10,5 liter dan sapi 21 gram/air 10,5 liter, K4 = pupuk kandang kambing 10,5 gram/air 10,5 liter dan sapi 31,5 gram/air 10,5 liter, K5 = pupuk kandang sapi 42 gram/air 10,5 liter. Homogenitas ragam data diuji dengan uji Bartlett, additivitas data diuji dengan uji Tukey, dan pengujian nilai tengah dengan uji Beda Nyata Terkecil (BNT) pada taraf 5\%. Hasil penelitian menunjukkan penggunaan Pupuk kandang kambing dan sapi serta campurannya dapat meningkatkan pertumbuhan dan perkembangan Azolla microphylla. Campuran pupuk kandang kambing $21 \mathrm{~g}$ dan sapi $21 \mathrm{~g}$ /air 10,5 liter merupakan perlakuan terbaik terhadap pertumbuhan populasi Azolla microphylla
\end{abstract}

Kata kunci: Azolla microphylla, kombinasi, populasi, pupuk kandang

\begin{abstract}
Azolla microphyllais a type of small fern that lives in the waters and beneficial as an organic fertilizer in lowland rice cultivation. Considering the use is increasing, it is necessary to conduct a research how to increase the growth and population of A. microphylla. The research was conducted at the Greenhouse and Weed Science Laboratory of the Faculty of Agriculture, University of Lampung from March to April 2020. The study used a completely randomized design (CRD) with four replications and six treatments so that there were 24 experimental units. As growing media, soil and 10.5 liters of water are filled in a tray measuring $30 \mathrm{~cm} \times 35 \mathrm{~cm}$. The treatments were $K O=$ without manure, $K 1=$ goat manure $42 \mathrm{~g}, \mathrm{~K} 2=$ goat manure $31,5 \mathrm{~g}$ plus cattle manure $10,5 \mathrm{~g}, \mathrm{~K} 3=$ goat manure $21 \mathrm{~g}$ plus cattle manure $21 \mathrm{~g}, \mathrm{~K} 4=$ goat manure $10,5 \mathrm{~g}$ plus cattle manure $31,5 \mathrm{~g}$, and $\mathrm{K} 5$ cattle manure $42 \mathrm{~g}$ that added in 10,5 liters of water. Homogeneity of data was tested using the Bartlett test, the additivity was tested with the Tukey test. The mean was tested with the least significant difference (LSD) at 5\% level. The results showed that the use of goat and cattle manures and the its mixture increased the growth and development of Azolla microphylla. The mixture of goat manure $21 \mathrm{~g}$ and cattle manure $21 \mathrm{~g} / 10.5$ liters water is the best treatment for population growth of Azolla microphylla.
\end{abstract}

Keywords: Azolla microphylla, cattle manure, combination, population 


\section{PENDAHULUAN}

Azolla microphylla merupakan salah satu jenis gulma tumbuhan paku air yang biasa tumbuh di perairan tenang seperti danau, kolam, sungai, dan sawah. Tumbuhan A. microphylla dapat bersimbiosis dengan Cyanobacteria, dimana dalam hubungan simbiosisnya dapat memfiksasi nitrogen udara (N). Kemampuan A.microphylla bersimbiosis menyebabkan tempat tumbuh dan biomassa mempunyai kualitas nutrisi yang baik khususnya nitrogen dan senyawa bentukannya seperti protein (Syafi'i, 2008).

Azolla microphylla memperbanyak diri secara generatif dan vegetatif. Perkembangan secara generatif berlangsung secara kompleks dengan spora, sedangkan vegetatif melalui cabang-cabang sisi memisahkan diri dari cabang induk diikuti oleh pembentukan penutup luka. Cabang cabang yang memisahkan diri tersebut kemudian menjadi tanaman dewasa (Ladha, 1983).

Tumbuhan Azolla microphylla dapat dijadikan sebagai pupuk organik Nitrogen (N) yang cocok dikembangkan oleh petani dan mudah diaplikasikan. Setiawan et al. (2020) melaporkan bahwa pemberian 50\% $\mathrm{NPK}+$ Azolla + pupuk hayati dapat meningkatkan gabah kering giling sebesar $10,82 \%$ dibandingkan dosis anjuran pupuk anorganik (100\% NPK) untuk tanaman padi walaupun tidak berbeda secara statistik akan tetapi dapat menghemat penggunaan pupuk anorganik sebesar $50 \%$.

Dalam upaya meningkatkan pertumbuhan Azolla sehingga cepat dapat dipanen dengan produktivitas yang tinggi maka perlu dilakukan pemupukan baik menggunakan pupuk anorganik NPK (Rosdiana et al., 2017) maupun menggunakan pupuk kandang. Surdina et al. (2016) melaporkan pencampuran pupuk kandang ayam $200 \mathrm{~g}$ per $\mathrm{m}^{2}$ tanah kolam memberikan pertumbuhan Azolla terbaik.

Pupuk organik digunakan karena salah satunya dapat mengurangi pencemaran lingkungan. Pupuk kandang kambing digunakan mengandung $\mathrm{N}$ dan $\mathrm{K}$ yang lebih tinggi dibandingkan dengan kotoran sapi serta unsur $\mathrm{P}$ yang setara dengan pupuk kandang lainnya (Musnamar, 2003). Pupuk kandang sapi memiliki kelebihan pada kadar serat yang lebih tinggi seperti selulosa, pupuk kandang sapi dapat memberikan manfaat pada tanaman yaitu menyediakan unsur hara makro dan mikro bagi tanaman (Hartatik dan Widowati, 2006). Kandungan unsur hara tersebut merupakan kebutuhan utama yang baik bagi pertumbuhan Azolla microphylla. Berdasarkan hal tersebut, perlu dilakukan penelitian mengenai pengaruh pemberian pupuk kandang kambing dan pupuk kandang sapi terhadap pertumbuhan A. microphylla.

\section{METODE PENELITIAN}

\section{Tempat dan Waktu}

Penelitian dilaksanakan di rumah kaca dan di Laboratorium Gulma Fakultas Pertanian Universitas Lampung dari bulan Maretsampai dengan April 2020.

\section{Bahan dan Alat}

Alat yang digunakan yaitu nampan dengan luas $30 \mathrm{~cm}$ x $35 \mathrm{~cm}, S P A D 502$, quick counter, jangka sorong, spidol, timbangan, oven, dan cangkul. Bahan yang digunakan yaitu Azolla microphylla, pupuk kandang kambing, pupuk kandang sapi, air, dan tanah.

\section{Rancangan Percobaan}

Penelitian menggunakan metode Rancangan Acak Lengkap (RAL) dengan 6 perlakuan yang diulang sebanyak 4 kali sehingga terdapat 24 petak percobaan yaitu perlakuan KO (Tanpa pupuk kandang), K1 (Pupuk kandang kambing 42 gram/10,5 liter air), K2 (Pupuk kandang kambing 31,5 gram/10,5 liter air dan sapi 10,5 gram/10,5 liter air), K3 (Pupuk kandang kambing 21 gram/10,5 liter air dan sapi 21 gram/10,5 liter air), K4 (Pupuk kandang kambing 10,5 gram/10,5 liter air dan sapi 31,5 gram/10,5 
liter air), dan K5 (Pupuk kandang sapi 42 gram/10,5 liter air).

\section{Tahapan Penelitian}

Media tanam yang digunakan berupa campuran tanah dengan ketebalan $3 \mathrm{~cm}$ dan air sebanyak 10,5 liter. Pengaplikasian pupuk dilakukan setelah 2 hari tercampur tanah dan air secara homogen dengan cara disebar secara merata. Kemudian penanaman dilakukan dengan cara menabur Azolla microphylla sebanyak 1 individu di setiap media tanam.

Parameter pengamatan diantarannya pertambahan populasi pada 7, 14, 21, 28 dan 35 Hari Setelah Tanam (HST) dilakukan secara visual. Panjang akar, diameter daun, kehijauan daun diamati dengan mengambil sampel sebanyak 5 individu pada saat panen. Pada bobot basah setelah dikeringanginkan dan bobot kering dilakukan pengeringan dalam oven dengan suhu $70^{\circ} \mathrm{C}$ selama 48 jam hingga bobotnya konstan.

\section{HASIL DAN PEMBAHASAN}

\section{Pertumbuhan dan Jumlah Individu}

Pemberian bahan organik berupa pupuk kandang kambing dan sapi serta kombinasinya dapat meningkatkan pertumbuhan/penambahan individu Azolla microphylla Gambar 1 menunjukkan bahwa pupuk kandang kambing dan sapi dapat meningkatkan pertumbuhan Azolla microphylla. Penggunaan kombinasi pupuk kandang kambing 21 gram dan sapi 21 gram memberikan pertumbuhan/ penambahan individu A.microphylla yang tertinggi hingga 35 HST yang dapat memenuhi areal nampan ukuran luas $30 \mathrm{~cm}$ x $35 \mathrm{~cm}$. Kombinasi pupuk kandang kambing 21 gram dan sapi 21 gram memberikan pertumbuhan $A$. microphylla dengan ratarata (2121,8 individu) dibandingkan lainnya dengan rata-rata tanpa pupuk kandang (710,75 individu), pupuk kandang kambing 42 gram (1091 individu), kombinasi pupuk kandang kambing 31,5 gram dan sapi 10,5 gram (1272,8 individu), kombinasi pupuk kandang kambing 10,5 gram dan sapi 31,5 gram (1869 individu), dan pupuk kandang sapi 42 (1514,3). Menurut Arifin (1996), pertumbuhan A. microphylla rata-rata 15-18 anak daun perharinya.

Hasil penelitian menunjukkan bahwa kebutuhan unsur hara untuk pertumbuhan Azolla microphylla harus sesuai. Kebutuhan unsur hara A. microphylla akan N sangat rendah disebabkan Azolla sp. melakukan simbiosis dengan Anabaena azollae yang menfiksasi $\mathrm{N}_{2}$ langsung di udara, apabila kandungan $\mathrm{N}$ tinggi pertumbuhan A.microphylla terhambat. Hasil penelitian Singh (1979) menunjukkan bahwa pemberian $\mathrm{N}$ mengakibatkan sel-sel Anabaena azollae menjadi kurang aktif bekerja karena kebutuhan nitrogennya telah terpenuhi. Unsur P merupakan unsur hara utama yang membatasi pertumbuhan dan perkembangan Azolla sp (Lumpkin dan Plucknet, 1982). Menurut Khan (1988), Azolla sp. membutuhkan P dapat larut dalam air secara kontinyu untuk pertumbuhan dan perkembangan. Oleh karena itu kebutuhan unsur hara khususnya $\mathrm{N}$ dan $\mathrm{P}$ harus tepat.

\section{Panjang Akar}

Tabel 1 menunjukkan bahwa kombinasi pupuk kandang kambing 10,5 gram dan sapi 31,5 gram menghasilkan akar yang lebih panjang dibandingkan tanpa penggunaan pupuk kandang, namun tidak berbeda dengan perlakuan pupuk kandang lainnya dengan nilai rata-rata $11,3 \mathrm{~cm}$. Penambahan bahan organik seperti pupuk kandang kambing dan sapi dapat mempengaruhi pertumbuhan akar menjadi lebih baik karena pupuk kandang kambing dan sapi mengandung banyak fosfor yang dapat merangsang pertumbuhan dan perkembangan akar. Tanaman yang kekurangan fosfor akan mengakibatkan perkembangan akar menjadi terhambat dan penyerapan unsur hara akan berkurang sehingga menghambat pertumbuhan tanaman bagian atas (Hardjowigeno, 2007). 
Keterangan:

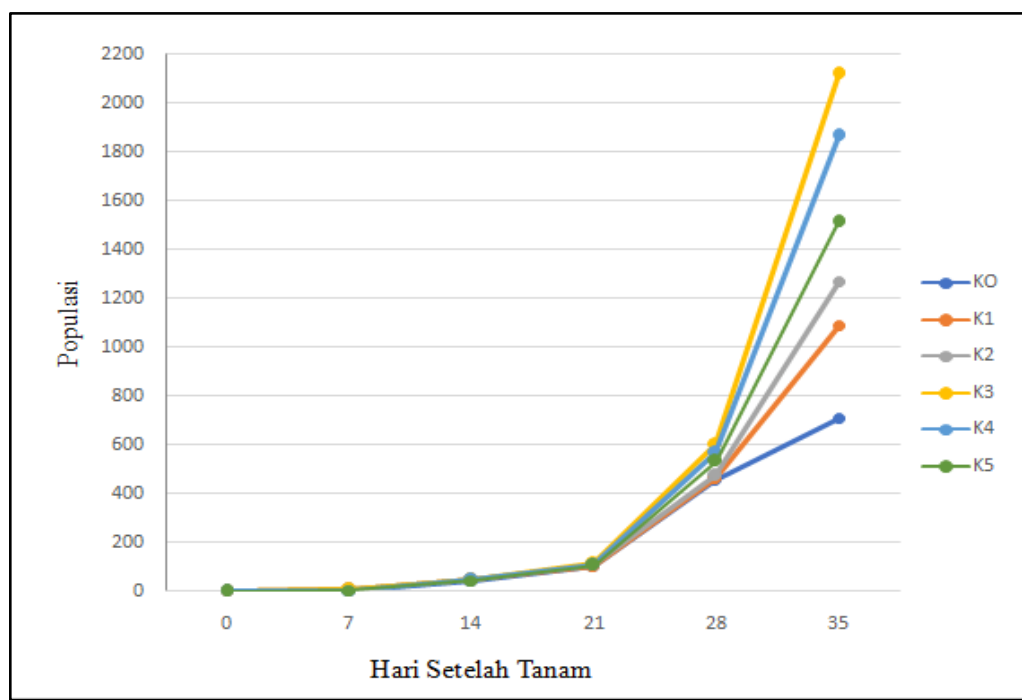

$\mathrm{K} 0$ = Tanpa pupuk kandang

$\mathrm{K} 1$ = Pupuk kandang kambing 42 gram.

$\mathrm{K} 2$ = Pupuk kandang kambing 31,5 gram dan sapi 10,5 gram.

$\mathrm{K} 3$ = Pupuk kandang kambing 21 gram dan sapi 21 gram.

K4 = Pupuk kandang kambing 10,5 gram dan sapi 31,5 gram.

K5 = Pupuk kandang sapi 42 gram.

Gambar 1. Grafik pertumbuhan populasi Azolla microphylla akibat perlakuan pupuk kendang kambing dan sapi.

Tabel 1. Panjang akar Azolla microphylla akibat pengaruh pupuk kandang kambing dan sapi.

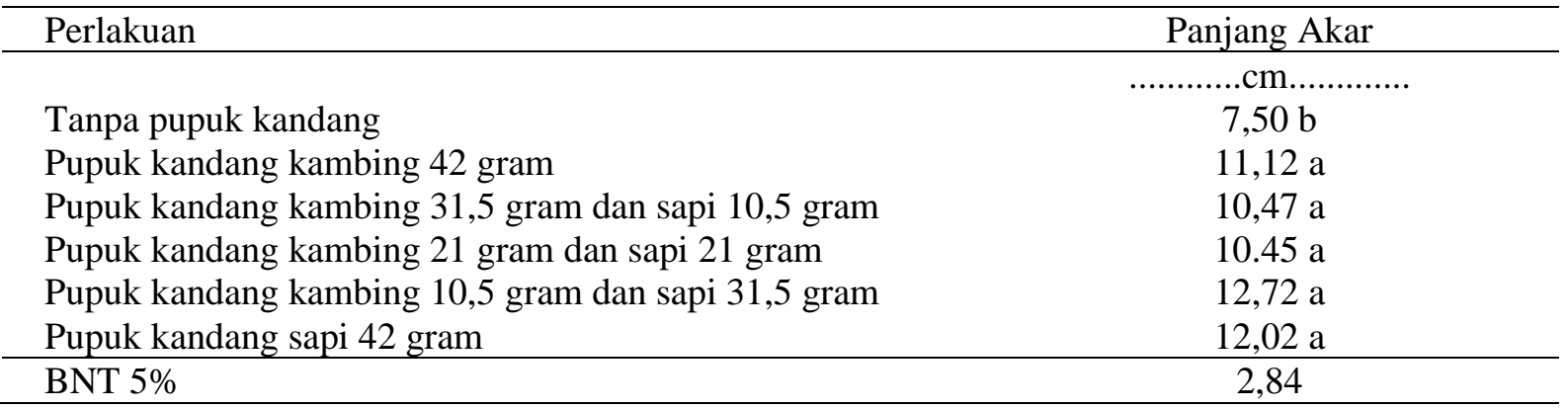

Keterangan : Nilai tengah pada setiap kolom yang diikuti dengan huruf yang sama tidak berbeda nyata menurut uji BNT pada taraf $5 \%$. 
Tabel 2. Diameter daun Azolla microphylla akibat pengaruh pupuk kandang kambing dan sapi.

\begin{tabular}{lc}
\hline Perlakuan & Diameter daun \\
\hline & $\ldots \ldots \ldots . . . \ldots m \ldots \ldots \ldots . . . . . . . . .$. \\
Tanpa pupuk kandang & $53,55 \mathrm{c}$ \\
Pupuk kandang kambing 42 gram & $63,64 \mathrm{~b}$ \\
Pupuk kandang kambing 31,5 gram dan sapi 10,5 gram & $63,52 \mathrm{~b}$ \\
Pupuk kandang kambing 21 gram dan sapi 21 gram & $78,79 \mathrm{a}$ \\
Pupuk kandang kambing 10,5 gram dan sapi 31,5 gram & $78,48 \mathrm{a}$ \\
Pupuk kandang sapi 42 gram & $75,50 \mathrm{a}$ \\
\hline BNT 5\% & 5,06 \\
\hline
\end{tabular}

Keterangan : Nilai tengah pada setiap kolom yang diikuti dengan huruf yang sama tidak berbeda nyata menurut uji BNT pada taraf $5 \%$.

\section{Diameter Daun}

Pada Tabel 2 dapat dilihat kombinasi pupuk kandang kambing 21 gram dan sapi 21 gram, kombinasi pupuk kandang kambing 10,5 gram dan sapi 31,5 gram, dan pupuk kandang sapi 42 gram menghasilkan diameter daun terlebar dibandingan tanpa penggunaan pupuk kandang dan dosis pupuk kandang lainnya. Kombinasi pupuk kandang tersebut menghasilkan diameter daun ratarata $77,59 \mathrm{~mm}$. Diameter daun berpengaruh pada tingkat penambahan biomassa $A$. microphylla (bobot basah dan kering). Hal ini karena jumlah diameter daun tertinggi terdapat pada perlakuan kombinasi pupuk kandang kambing 21 gram dan sapi 21 gram yang dihasilkan sama seperti biomassa $A$. microphylla. Diameter daun yang luas memiliki permukaan daun yang relatif lebar, sehingga dari proses fotosintesis yang didapat menghasilkan energi yang lebih banyak sehingga laju produksi biomassanya juga meningkat. Hal ini sesuai dengan pernyataan Sitompul dan Guritno (1995), bahwa semakin bertambah waktu pertumbuhan dua tanaman dengan spesies sama akan membentuk daun yang lebih luas sejalan dengan perkembangan tanaman. Produksi fotosintat yang lebih besar memungkinkan pembentukan seluruh organ tanaman yang relatif besar seperti daun dan akar yang kemudian akan menghasilkan produksi bahan kering yang semakin besar.

\section{Kehijauan Daun}

Tabel 3 menunjukkan bahwa penggunaan pupuk kandang sapi 42 gram menghasilkan tingkat kehijaun yang lebih tinggi dibandingkan tanpa penggunaan pupuk kandang. Antar penggunaan pupuk kandang lainnya, pupuk kandang sapi 42 gram menghasilkan tingkat kehijauan tertinggi dengan nilai rata-rata 9,28 unit. Hasil penelitian Kurnianingsih et al. (2018), menjelaskan bahwa perlakuan kombinasi tanah dan pupuk kandang berbanding lurus dengan tingkat kehijauan daun. Daun yang lebih hijau dan memiliki tingkat kehijauan daun lebih tinggi akan menghasilkan klorofil yang lebih banyak.

\section{Bobot Basah dan Bobot Kering}

Tabel 4 menunjukkan kombinasi pupuk kandang kambing 21 gram dan sapi 21 gram, kombinasi pupuk kandang kambing 10,5 gram dan sapi 31,5 gram, dan pupuk kandang sapi 42 gram menghasilkan bobot basah lebih tinggi dibandingan tanpa penggunaan pupuk kandang. Antar penggunaan pupuk kandang lainnya, kombinasi pupuk kandang kambing 21 gram dan sapi 21 gram cenderung menghasilkan bobot basah yang lebih baik yaitu rata-rata 5,52 gram. Pada bobot kering $A$. microphylla kombinasi kombinasi pupuk kandang kambing 21 gram dan sapi 21 gram menghasilkan bobot kering yang lebih tinggi dibandingkan tanpa penggunaan pupuk 
kandang. Antar penggunaan pupuk kandang lainnya perlakuan tersebut menghasilkan bobot kering yang lebih baik nilai rata-rata 4,60 gram. Kombinasi pupuk kandang kambing 21 gram dan sapi 21 gram memiliki Biomassa (bobot basah dan bobot kering)
A.microphylla yang tertinggi hal ini diduga adanya penambahan individu setelah mengalami pertumbuhan yang maksimum pada masa panen.

Tabel 3. Kehijauan daun Azolla microphylla akibat pengaruh pupuk kandang kambing dan sapi.

\begin{tabular}{ll}
\hline \multicolumn{1}{c}{ Perlakuan } & Kehijauan daun \\
\hline & $\ldots \ldots \ldots .$. Unit........... \\
Tanpa pupuk kandang & $34,05 \mathrm{~d}$ \\
Pupuk kandang kambing 42 gram & $42,32 \mathrm{~cd}$ \\
Pupuk kandang kambing 31,5 gram dan sapi 10,5 gram & $53,90 \mathrm{bc}$ \\
Pupuk kandang kambing 21 gram dan sapi 21 gram & $45,85 \mathrm{bcd}$ \\
Pupuk kandang kambing 10,5 gram dan sapi 31,5 gram & $57,30 \mathrm{~b}$ \\
Pupuk kandang sapi 42 gram & $85,70 \mathrm{a}$ \\
\hline BNT 5\% & 14,52 \\
\hline
\end{tabular}

Keterangan : Nilai tengah pada setiap kolom yang diikuti dengan huruf yang sama tidak berbeda nyata menurut uji BNT pada taraf $5 \%$.

Tabel 4. Bobot basah dan bobot kering Azolla microphylla akibat pengaruh pupuk kandang kambing dan sapi.

\begin{tabular}{lccc}
\hline \multicolumn{1}{c}{ Perlakuan } & \multicolumn{2}{c}{ Bobot basah } & \multirow{2}{*}{$\begin{array}{c}\text { Bobot } \\
\text { kering }\end{array}$} \\
\cline { 2 - 3 } & Asli & \multicolumn{1}{l}{$(\mathrm{X}+0,5)$} & k...... gram ............ \\
\hline Tanpa pupuk kandang & 12,4 & $3,65 \mathrm{c}$ & $2,57 \mathrm{~b}$ \\
Pupuk kandang kambing 42 gram & 17,38 & $4,18 \mathrm{bc}$ & $3,87 \mathrm{ab}$ \\
Pupuk kandang kambing 31 dan sapi 10,5 gram & 23,27 & $4,85 \mathrm{ab}$ & $3,28 \mathrm{ab}$ \\
Pupuk kandang kambing 21 gram dan sapi 21gram & 31,05 & $5,52 \mathrm{a}$ & $4,60 \mathrm{a}$ \\
Pupuk kandang kambing 10,5 dan sapi 31 gram & 28,25 & $5,35 \mathrm{a}$ & $3,85 \mathrm{ab}$ \\
Pupuk kandang sapi 42 gram & 28,34 & $5,34 \mathrm{a}$ & $3,85 \mathrm{ab}$ \\
\hline BNT 5\% & & 0,98 & 1,41 \\
\hline
\end{tabular}

Keterangan : Nilai tengah pada setiap kolom yang diikuti dengan huruf yang sama tidak berbeda nyata menurut uji BNT pada taraf $5 \%$.

Bobot basah dan kering berkaitan dengan pertumbuhan/penambahan individu Azolla microphylla. Besarnya nilai bobot basah cenderung akan mempengaruhi nilai bobot kering total Azolla microphylla karena sebagian besar tanaman ini tersusun dari daun. Daun merupakan organ utama fotosintesis pada tumbuhan tingkat tinggi. Penambahan unsur hara mempengaruhi peningkatan bobot basah dan kering A.microphylla.

Hasil penelitian Surdina (2016), menyatakan bahwa Azolla microphylla menyerap nutrisi yang terdapat pada pupuk kandang sehingga media tanam yang diperkaya dengan unsur fosfat cenderung meningkatkan produktivitas tanaman $A$. microphylla dan aktivitas penambatan 
nitrogen oleh Anabaena azollae sangat mempengaruhi pertumbuhan tanaman Azolla sp. karena nitrogen hasil fiksasi akan didistribusikan ke sel Azolla sp. yang selanjutkan akan digunakan untuk pertumbuhan tanaman Azolla sp.

\section{KESIMPULAN}

Dari percobaan ini dapat diambil simpulan bahwa: penggunaan pupuk kandang kambing dan sapi serta kombinasinya dapat meningkatkan pertumbuhan populasi, panjang akar, diameter daun, kehijauan daun, bobot basah dan bobot kering Azolla microphylla. Selain itu penggunaan kombinasi pupuk kandang kambing 21 gram dan sapi 21 gram dapat menghasilkan jumlah populasi tertinggi dibandingkan perlakuan lainnya

\section{DAFTAR PUSTAKA}

Arifin, Z. 1996. Azolla Pembudidayaan dan Pemanfaatan pada Tanaman Padi. Penebar Swadaya. Jakarta. $57 \mathrm{hlm}$.

Hardjowigeno, S. 2007. Ilmu Tanah. Mediatama Sarana Perkasa. Jakarta. 237 hlm.

Hartatik, W. dan L.R. Widowati. 2006. Pupuk Kandang. Dalam R.D.M. Simanungkalit (Eds.). Pupuk Organik dan Pupuk Hayati. Hlm. 59-82.

Khan, M.M. 1988. A Primer on Azolla Production \& Utilization in Agriculture. Institute of Biological Sciences of the University of the Phillippines. Phillippines $150 \mathrm{hlm}$

Kurnianingsih, A. , Susilawati dan M. Sefrila. 2018. Karakteri Pertumbuhan Tanaman
Bawang Merah Pada Berbagai isi Media Tanam. J. Hortikultura. 9(3): 167-173.

Ladha. 1987. Biochemical Basis Of AzollaAnnabaena Azolla Simbion. Procceding of the workshop on Azolla Use Manila. Philippines. Pp: 89-95

Lumpkin,T. A., dan D. L. Plucknett. 1982. Azollaas green manure: Use and management in crop production. Westview Press. Colorado. $230 \mathrm{hlm}$.

Musnamar, E.I. 2003. Pupuk organik cair dan padat, pembuatan, dan aplikasi. Penebar Swadaya. Jakarta. $72 \mathrm{hlm}$.

Rosdiana, E. Ayuzar, dan Zulfikar. 2017. Pengaruh pemberian pupuk buatan yang berbeda terhadap kelimpahan Azolla sp. Acta Aquatica Aquatic Sciences Journal, 4(1): 33-36.

Setiawan, M.R., B.N. Fitriatin, P. Suryatmana, dan T. Simarmata. 2020. Aplikasi pupuk hayati dan Azolla untuk mengurangi dosis pupuk anorganik dan meningkatkan N, P, C organik tanah, dan N, P tanaman, serta hasil padi sawah. Jurnal Agroteknologi, 12(1): 63-76.

Singh, P.K. 1997. Use of Azolla in rice production in india. In IRRI edition Nitrogen and Rice. Los Banos. Laguna. Philippines. Pp. 407-419.

Sitompul, S.M., dan B. Guritno. 1995. Analisis Pertumbuhan Tanaman. Gadjah Mada University Press. Yogyakarta.412 hlm.

Surdina, E., S.A. El-Rahimi, dan I. Hasri. 2016. Pertumbuhan Azolla microphylla Dengan Kombinasi Pupuk Kotoran Ternak. Jurnal ilmiah Mahasiswa Kelautan dan Perikanan Unsyiah, 1(3): 298-306.

Syafi'i, A. K. 2008. Petunjuk Praktis Membudidayakan Azolla. Binamuda Ciptakreasi, Depok. $50 \mathrm{hlm}$ 